\title{
Teaching for Extrinsic Motivation ${ }^{1}$
}

\author{
Isabella Damiani, Andrew Thoron, and J. C. Bunch²
}

Motivation is the idea of being moved to do something (Ryan \& Deci, 2000). Individuals have different degrees of motivation. Level of motivation and type of motivation are important when evaluating an individual's overall motivation. Based on the Self-Determination Theory, there are two main types of motivation: intrinsic and extrinsic motivation (Deci \& Ryan, 1985). Intrinsic motivation is derived from internal reward and enjoyment from completing a task. However, extrinsic motivation is fueled by external rewards or an expected outcome.

Extrinsic motivation is viewed to be autonomous; however, there are important considerations to be made. Extrinsic motivation is often viewed as the less effective form of motivation. However, this type of motivation can also be representative of lively actions. Individuals are working towards an end goal and thus driven by the accomplishment of this goal. Extrinsic motivation varies in its degree of autonomy. For example, an individual who is extrinsically motivated to do well in school may have varying reasons for this. The individuals may be motivated due to fear of failure. They could be motivated to do well for financial reward from family members. Extrinsic motivation can encompass completing actions with resentment and displeasure or with excitement and hope (Ryan \& Deci, 2000).

\section{Teaching and Learning with Extrinsic Motivation}

It is not feasible for educators to believe their students will always be driven by intrinsic motivation. It is valuable to use extrinsic motivation effectively, especially when students are expected to perform typically unexciting activities. Individuals who are extrinsically motivated are working towards a specific outcome. Their motivation is towards an end goal, rather than the process or task at hand. Ryan and Deci (2000) identified four types of extrinsic motivation and examples of each are provided below:

Table 1. Types of extrinsic motivation.

\begin{tabular}{|l|l|l|}
\hline $\begin{array}{l}\text { External } \\
\text { Regulation }\end{array}$ & $\begin{array}{l}\text { Focuses on } \\
\text { extrinsic rewards or } \\
\text { punishments }\end{array}$ & $\begin{array}{l}\text { A student performs well } \\
\text { on a test to that they can } \\
\text { participate in their sport } \\
\text { team's game. }\end{array}$ \\
\hline Introjection & $\begin{array}{l}\text { Ego-involved, } \\
\text { focuses on approval } \\
\text { from self or others }\end{array}$ & $\begin{array}{l}\text { The student is working to } \\
\text { perform well so that they are } \\
\text { not ridiculed by their peers. }\end{array}$ \\
\hline Identification & $\begin{array}{l}\text { Values importance } \\
\text { of activity }\end{array}$ & $\begin{array}{l}\text { The student has memorized } \\
\text { the components of the cell, } \\
\text { because they see this as a } \\
\text { valuable skill for life, and } \\
\text { thus sees the importance for } \\
\text { future success. }\end{array}$ \\
\hline Integration & $\begin{array}{l}\text { Regulates into } \\
\text { congruence with } \\
\text { personal values }\end{array}$ & $\begin{array}{l}\text { The student completes the } \\
\text { report because they truly } \\
\text { are interested in the topic; } \\
\text { however, the student is still } \\
\text { completing the report to } \\
\text { receive a grade. }\end{array}$ \\
\hline
\end{tabular}

1. This document is AEC644, one of a series of the Agricultural Education and Communication Department, UF/IFAS Extension. Original publication date June 2018. Visit the EDIS website at http://edis.ifas.ufl.edu.

2. Isabella Damiani, graduate assistant; Andrew Thoron, associate professor; and J. C. Bunch, assistant professor; Department of Agricultural Education and Communication, UF/IFAS Extension, Gainesville, FL 32611.

The Institute of Food and Agricultural Sciences (IFAS) is an Equal Opportunity Institution authorized to provide research, educational information and other services only to individuals and institutions that function with non-discrimination with respect to race, creed, color, religion, age, disability, sex, sexual orientation, marital status, national origin, political opinions or affiliations. For more information on obtaining other UF/IFAS Extension publications, contact your county's UF/IFAS Extension office. 
Educators are ultimately preparing students to promote learning. As students age, the complexity of the material they are learning matures with them. Students will lack maturity in their later lives if they are primarily extrinsically motivated. Thus, it is important for teachers to use extrinsic motivation in constructive ways. However, educators must be aware of the types of extrinsic motivation and focus on identification and integration rather than introjection and external regulation.

Understanding of theories related to extrinsic motivation aids in educators' capability to effectively motivate their students. Outlined below are five theories related to extrinsic motivation:

Table 2. Theories related to extrinsic motivation (Schnuck, 2012).

\begin{tabular}{|l|l|}
\hline Goal Theory & $\begin{array}{l}\text { States that relationships exist among } \\
\text { motivational orientation, ability, social } \\
\text { comparisons, and achievement behaviors }\end{array}$ \\
\hline $\begin{array}{l}\text { Achievement } \\
\text { Motivation }\end{array}$ & $\begin{array}{l}\text { Seeking to become competent in specific } \\
\text { activities }\end{array}$ \\
\hline $\begin{array}{l}\text { Self-Worth Theory } \\
\text { Maslow's Hierarchy } \\
\text { of Needs }\end{array}$ & $\begin{array}{l}\text { Focus on failure shows low ability and should } \\
\text { be avoided }\end{array}$ \\
\hline $\begin{array}{l}\text { An increasingly important pyramid of needs } \\
\text { in the following order: physiological, safety, } \\
\text { belongingness, esteem, self-actualization }\end{array}$ \\
\hline Theory & Motivated by stimuli that initiates a response \\
\hline
\end{tabular}

\section{Examples of Extrinsic Motivation}

- Student Accountability/Competition

- Display students' successes on a board, perhaps called a "super-star board," to encourage students to work harder and earn their own place on the "super-star board".

- Incentives

- A child may earn a star, sticker, treat, or other form of reward when they excel at a task.

- Responses Cost Systems

- In this system, students may earn points for positive behavior, but lose them when behavior is negative. The students may use these points for things such as extra credit, prizes, or extra responsibility.

\section{References}

Deci, E. L., and Ryan, R. M. (1985). Intrinsic motivation and self-determination in human behavior. New York: Plenum.

Ryan, R. M., and Deci, E. L. (2000). Intrinsic and extrinsic motivations: classic definitions and new directions. Contemporary Educational Psychology, 25, 54-67. doi:10.1006/ ceps. 1999.1020

Schunk, D. H. (2012). Learning theories: An educational perspective. Boston: Pearson. 